\title{
Analisis Perubahan Konseptual Mahasiswa Pada Materi Kimia Larutan Melalui Penerapan Model Pembelajaran PS-Trilogi Berorientasi Kearifan Lokal
}

\author{
Afadil $^{1 *}$ dan Anang WM Diah ${ }^{1}$ \\ ${ }^{1}$ Program Studi Pendidikan Kimia FKIP Universitas Tadulako \\ Jl. Soekarno Hatta Km 9, Palu-Indonesia, 94118 \\ *sukarmanafadil@yahoo.co.id
}

\begin{abstract}
Abstrak
Jenis penelitian ini merupakan pre-experimental dengan One Group Pretest-Postest Design. Tujuan penelitian adalah untuk menganalisis perubahan konseptual mahasiswa pada materi Kimia Larutan melalui penerapan model pembelajaran PS-TRILOGI berorientasi kearifan lokal. Sampel penelitian adalah mahasiswa semester genap tahun ajaran 2017/2018 yang memprogramkan mata kuliah Kimia Dasar II pada Program Studi Pendidikan Kimia FKIP UNTAD. Teknik analisis konsepsi mahasiswa menggunakan Certainty of Response Index (CRI) berdasarkan pada suatu skala enam (0-5). Hasil analisis secara klasikal yang diperoleh bahwa penerapan model pembelajaran PS-TRILOGI berorientasi kearifan lokal mampu mereduksi Miskonsepsi (MK) mahasiwa pada materi Kimia Larutan sebesar 12,2\%; mampu meningkatkan Tahu Konsep (TK) mahasiswa sebesar 26,9\%; dan mampu mereduksi Tidak Tahu Konsep (TTK) mahasiswa sebesar $16,6 \%$.
\end{abstract}

Kata Kunci: Kearifan Lokal, Kimia Larutan, Konsepsi, Model Pembelajaran PS-TRILOGI

\section{Pendahuluan}

Ilmu kimia umumnya diperoleh dan dikembangkan berdasarkan eksperimen yang melibatkan keterampilan dan penalaran dalam mencari jawaban atas pertanyaan apa, bagaimana, dan untuk apa gejala alam khususnya yang berkaitan dengan komposisi, struktur, sifat, transformasi, dinamika, dan energetika zat. Bila dipandang dari sisi filsafat ilmu, konsep-konsep dalam sains (termasuk kimia) mengacu pada tiga pertanyaan, yaitu berkaitan dengan aspek ontologi, epistemologi, dan aksiologi. Hal ini menunjukkan bahwa untuk memahami dan memecahkan masalah pada pembelajaran kimia diperlukan kajian yang mendalam terhadap konsep-konsep kimia dalam pembelajaran.

Berdasar pemahamannya terhadap sebuah konsep, sejumlah orang dapat dikelompokkan menjadi tiga yaitu orang yang tahu konsep (TK), tidak tahu konsep (TTK), dan miskonsepsi (MK). Miskonsepsi adalah ketidaksesuaian pemahaman konsep mahasiswa dengan pengertian ilmiah yang dirumuskan oleh ilmuwan di bidangnya [5]. Definisi miskonsepsi seperti ini juga dikemukakan oleh Berg, Kohle, dan Norland [12] dan [13]. Mahasiswa yang memahami konsep sesuai dengan yang didefinisi oleh ilmuwan dinyatakan sebagai mahasiswa yang tidak mengalami miskonsepsi.

Miskonsepsi mahasiswa pada konsep kimia sangat mungkin terjadi karena pada mata kuliah kimia terdapat konsep yang tidak mudah dipahami kecuali dihubungkan dengan sesuatu dari pengalaman sehari-hari. Oleh karena itu, maka pemahaman konsep secara utuh dan mendalam perlu diperkenalkan kepada mahasiswa sebagai salah satu langkah untuk mengatasi terjadinya miskonsepsi. Miskonsepsi yang sering dialami oleh peserta didik adalah konsep atom, molekul, stoikiometri, perubahan fasa, termokimia, larutan, kesetimbangan kimia, pembakaran, reaksi asam basa, laju reaksi (kinetika kimia), radiokimia, dan reaksi oksidasi-reduksi [9]. 
Fenomena miskonsepsi pada siswa, mahasiswa, guru, dosen atau siapa pun tidak boleh dibiarkan karena miskonsepsi merupakan penghambat untuk memahami konsep-konsep berikutnya. Miskonsepsi harus diusahakan untuk diperbaiki dengan perubahan konseptual [4]. Cara untuk mengatasi miskonsepsi menurut [13] dapat dilakukan mengikuti urutan sebagai berikut: (1) mencari atau mengungkap miskonsepsi yang dialami mahasiswa, (2) mencoba menemukan penyebab miskonsepsi tersebut, dan (3) mencari perlakuan yang sesuai untuk mengatasi.

Menurut [6] bahwa masalah mendasar dalam pembelajaran kimia yang menyebabkan terjadinya miskonsepsi pada mahasiswa saat ini adalah (1) diperolehnya pemahaman kimia oleh peserta didik yang tidak utuh, dan (2) tidak optimalnya perkembangan keterampilan berpikir tingkat tinggi (Higher Order of Thinking Skills = HOTS). Selanjutnya dijelaskan bahwa untuk melaksanakan pembelajaran kimia yang sesuai dengan tuntutan Kurikulum 2013 diperlukan: (1) pemahaman materi kimia secara mendasar oleh pengajar (2) kemampuan pengajar dalam memanfaatkan materi pelajaran untuk meningkatkan karakter dan HOTS peserta didik, dan (3) kemampuan pengajar untuk memanfaatkan secara optimal Teknologi Informasi dan Komunikasi (TIK) dalam pembelajaran.

Penelitian yang telah dilakukan oleh [2] dilaporkan bahwa melalui penerapan RPP pada pembelajaran Kimia Dasar II khususnya materi Kinetika Kimia pada mahasiswa Kelas A Program Studi Pendidikan Kimia FKIP UNTAD Tahun Ajaran 2016/2017 diperoleh persentase miskonsepsi (MK) yang dialami untuk semua konsep mengalami reduksi rata-rata 10,48\%. Persentase Tahu Konsep (TK) mahasiswa mengalami kenaikan rata-rata 14,6\%, dan persentase Tidak Tahu Konsep (TTK) mahasiswa mengalami reduksi rata-rata 5,44\%. Hasil tersebut menunjukkan bahwa persentase reduksi dan perubahan yang diperoleh untuk konsepsi mahasiswa pada materi Kinetika Kimia masih rendah.

Berdasarkan uraian di atas, maka diperlukan suatu upaya prevensi yang tepat melalui penerapan suatu model pembelajaran tertentu agar mahasiswa dapat memahami dan menyelesaikan masalah dengan kajian yang mendalam (filosofis) terhadap konsep-konsep kimia. Oleh karena itu, pada penelitian ini akan dilakukan penerapan model pembelajaran Problem Solving dengan Aspek Ontologi, Epistemologi, dan Aksiologi (PS-TRILOGI). Model pembelajaran $P S$-TRILOGI adalah salah satu model pembelajaran yang berfokus pada penyelesaian masalah (problem solving) yang melakukan kajian konsep melalui aspek ontologi, epistemologi, dan aksiologi dengan tahapan-tahapan pembelajaran yaitu identifikasi kesulitan, merencanakan penyelesaian masalah, implementasi rencana, mengomunikasikan, pengecekan kembali, dan evaluasi [1]. Artinya, model pembelajaran PS-TRILOGI dapat dijadikan sebagai salah satu model pembelajaran untuk mengajarkan materi kimia secara mendalam dan bermakna dalam melakukan kajian konsep berdasarkan aspek ontologi, epistemologi, dan aksiologi. Oleh karena itu, penerapan model pembelajaran ini diharapkan dapat menjadi solusi untuk mereduksi dan prevensi miskonsepsi mahasiswa pada pembelajaran kimia.

Selain itu, untuk memudahkan mahasiswa memahami konsep-konsep yang dipelajari, maka kajian konsep melalui aspek ontologi, epistemologi, dan aksiologi tersebut akan dihubungkan dengan kearifan lokal yang ada di Sulawesi Tengah. Hal ini sesuai dengan pendapat [3], bahwa pengembangan suatu model atau perangkat pembelajaran yang sesuai dengan karekteristik peserta didik akan memandu peserta didik dalam proses pembelajaran sehingga menentukan aktif-tidaknya dalam proses belajar, menentukan kecakapan hidup, menentukan kemampuan peserta didik mengkonstruksi pengetahuan, dan menentukan kebermaknaan belajar. Oleh karena itu, melalui penerapan model pembelajaran PS-TRILOGI yang berorientasi kearifan lokal diharapkan dapat mereduksi dan menjadi prevensi miskonsepsi mahasiswa yang dihasilkan dari penerapan proses pembelajaran pada mata kuliah Kimia Dasar II khususnya materi Kimia Larutan. 


\section{Metodologi}

Jenis Penelitian ini merupakan pra-eksperimen (pre-experimental). Desain yang digunakan adalah One Group Pretest-Posttest Design . Jenis penelitian ini sesuai dengan pendapat [7] yang di dalamnya terdapat langkah-langkah yang menunjukkan suatu urutan kegiatan penelitian, yaitu:

\begin{tabular}{|c|c|c|}
\hline $\mathrm{O} 1$ & $\mathrm{X}$ & $\mathrm{O} 2$ \\
\hline Pretest & Treatment & Posttest \\
\hline & & \\
\hline
\end{tabular}

Penelitian dilakukan di Fakultas Keguruan dan Ilmu Pendidikan pada Program Studi Pendidikan Kimia. Obyek penelitian adalah mahasiswa Semester Genap Tahun Ajaran 2017/2018 yang memprogramkan mata kuliah Kimia Dasar II pada kelas A dengan jumlah 34 mahasiswa. Instrumen yang disusun terdiri dari perangkat pembelajaran, lembar observasi, dan lembar tes. Semua instrumen yang disusun dilengkapi dengan lembar penilaian untuk divalidasi oleh ahli.

Analisis data konsepsi mahasiswa menggunakan Certainty Of Response Index (CRI) . CRI merupakan teknik untuk mengukur miskonsepsi seseorang dengan cara mengukur tingkat keyakinan atau kepastian seseorang dalam menjawab setiap pertanyaan yang diberikan. CRI biasanya berdasarkan pada suatu skala yang tetap, dalam penelitian skala yang digunakan adalah skala enam (0-5) seperti yang dikemukakan oleh [8] disajikan dalam Tabel 1.

Tabel 1. Pilihan dan Kategori Konsepsi Siswa

\begin{tabular}{|c|l|}
\hline Pilihan & \multicolumn{1}{|c|}{ Kategori } \\
\hline 0 & $\begin{array}{l}\text { Totally Guessed Answer: Jika menjawab soal 100\% ditebak atau menebak } \\
\text { sepenuhnya. }\end{array}$ \\
\hline 1 & $\begin{array}{l}\text { Almost Guesss: Jika dalam menjawab soal persentase unsur tebakan antara 75\%-99\% } \\
\text { atau hampir menebak. }\end{array}$ \\
\hline 2 & $\begin{array}{l}\text { Not Sure: Jika dalam menjawab soal persentase unsur tebakan antara 50\%-74\% atau } \\
\text { tidak yakin. }\end{array}$ \\
\hline 3 & $\begin{array}{l}\text { Sure: Jika dalam menjawab soal persentase unsur tebakan antara 25\%-49\% atau } \\
\text { yakin. }\end{array}$ \\
\hline 5 & $\begin{array}{l}\text { Almost Certain: Jika dalam menjawab soal persentase unsur tebakan antara 1\%-24\% } \\
\text { atau hampir pasti. }\end{array}$ \\
\hline Certain: Jika dalam menjawab soal tidak ada unsur tebakan sama sekali (0\%) atau \\
pasti.
\end{tabular}

Ketentuan kriteria jawaban berdasarkan CRI ditetapkan berdasarkan Tabel 2.

Tabel 2. Kriteria Jawaban Setiap Mahasiswa untuk Setiap Pertanyaan Didasarkan pada Kombinasi dari Jawaban Benar atau Salah dan Tinggi Rendahnya CRI

\begin{tabular}{|c|c|c|}
\hline $\begin{array}{l}\text { Kriteria } \\
\text { Jawaban }\end{array}$ & CRI Rendah $(<2,5)$ & CRI Tinggi $(>2,5)$ \\
\hline Jawaban benar & $\begin{array}{lccc}\text { Jawaban } & \text { benar } & \text { tetapi } & C R I \\
\text { rendah } & \text { berarti } & \text { tidak } & \text { tahu } \\
\text { konsep } & & & \\
\end{array}$ & $\begin{array}{l}\text { Jawaban benar dan } C R I \text { tinggi } \\
\text { berarti menguasai konsep dengan } \\
\text { baik. }\end{array}$ \\
\hline Jawaban salah & $\begin{array}{lcrr}\text { Jawaban } & \text { salah } & \text { dan } & C R I \\
\text { rendah } & \text { berarti } & \text { tidak } & \text { tahu } \\
\text { konsep. } & & & \\
\end{array}$ & $\begin{array}{l}\text { Jawaban salah tetapi } C R I \text { tinggi } \\
\text { berarti terjadi miskonsepsi. }\end{array}$ \\
\hline
\end{tabular}

\section{Hasil dan Pembahasan}

Pengelompokkan konsep Kimia Larutan yang diajarkan pada mahasiswa terdiri dari 10 konsep. Sedangkan pengelompokkan konsepsi mahasiswa Kelas A Program Studi Pendidikan 
Kimia FKIP UNTAD berdasarkan hasil pretest dalam TK, TTK, dan MK pada masing-masing konsep yang merepresentasi konsep Kimia Larutan disajikan pada Gambar 1 dan 2.

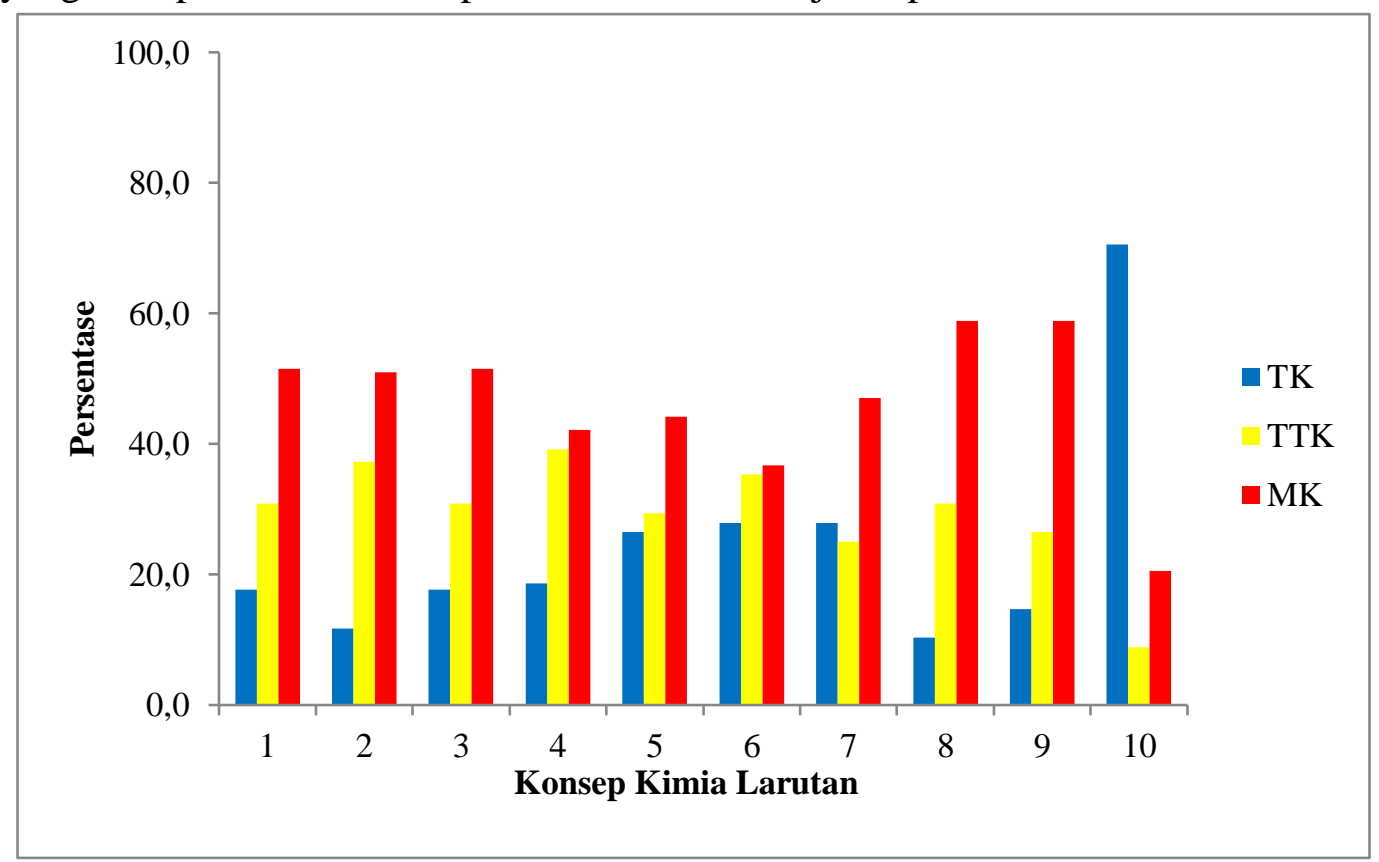

Gambar 1. Grafik Perbandingan Persentase Konsepsi Mahasiswa kelas A Program Studi Pendidikan Kimia FKIP yang TK, TTK, dan MK pada Pelaksanaan Pretest

Secara umum dapat digambarkan:

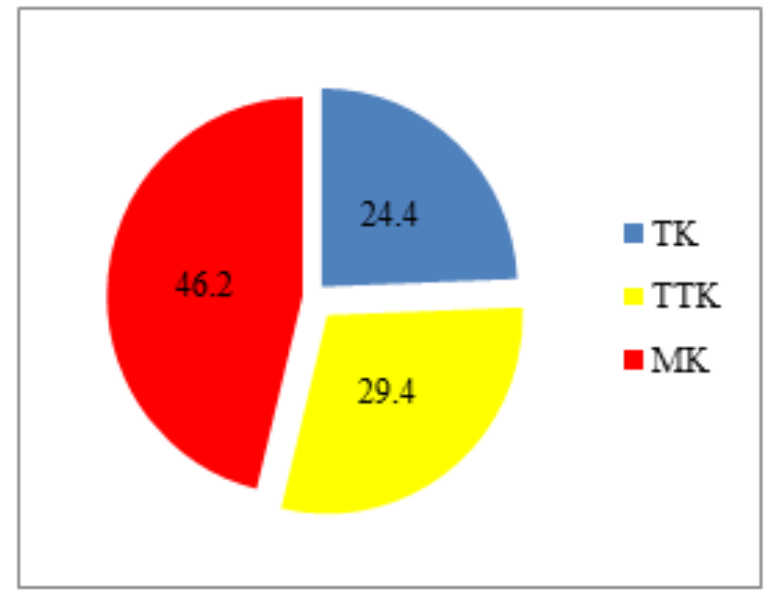

Gambar 2. Perbandingan Persentase Konsepsi Mahasiswa kelas A Program Studi Pendidikan Kimia FKIP yang TK, TTK, dan MK pada Pelaksanaan Pretest

Berdasarkan Gambar 1 dan 2, tampak bahwa: (1) dari 10 konsep yang diujikan semua menyebabkan siswa mengalami miskonsepsi, (2) Konsep yang direspon miskonsepsi secara kuat $(\mathrm{MK}>50 \%)$ terjadi pada konsep nomor 1, 2, 3, 8, dan 9. Sedangkan konsep 4, 5, 6, 7, dan 10 direspon miskonsepsi secara lemah ( $\mathrm{MK}<50 \%)$. Identifikasi miskonsepsi secara klasikal digunakan untuk menetapkan konsep yang diduga paling kuat miskonsepsinya dari 10 konsep yang diujikan didasarkan pada data CRIB, CRIS, dan fb untuk masing-masing butir tes yang merepresentasi konsep-konsep dalam materi Kimia Larutan. Data CRIB, CRIS, dan fb yang dihitung dari hasil pretest disajikan dalam bentuk grafik seperti ditunjukkan pada Gambar 3. 


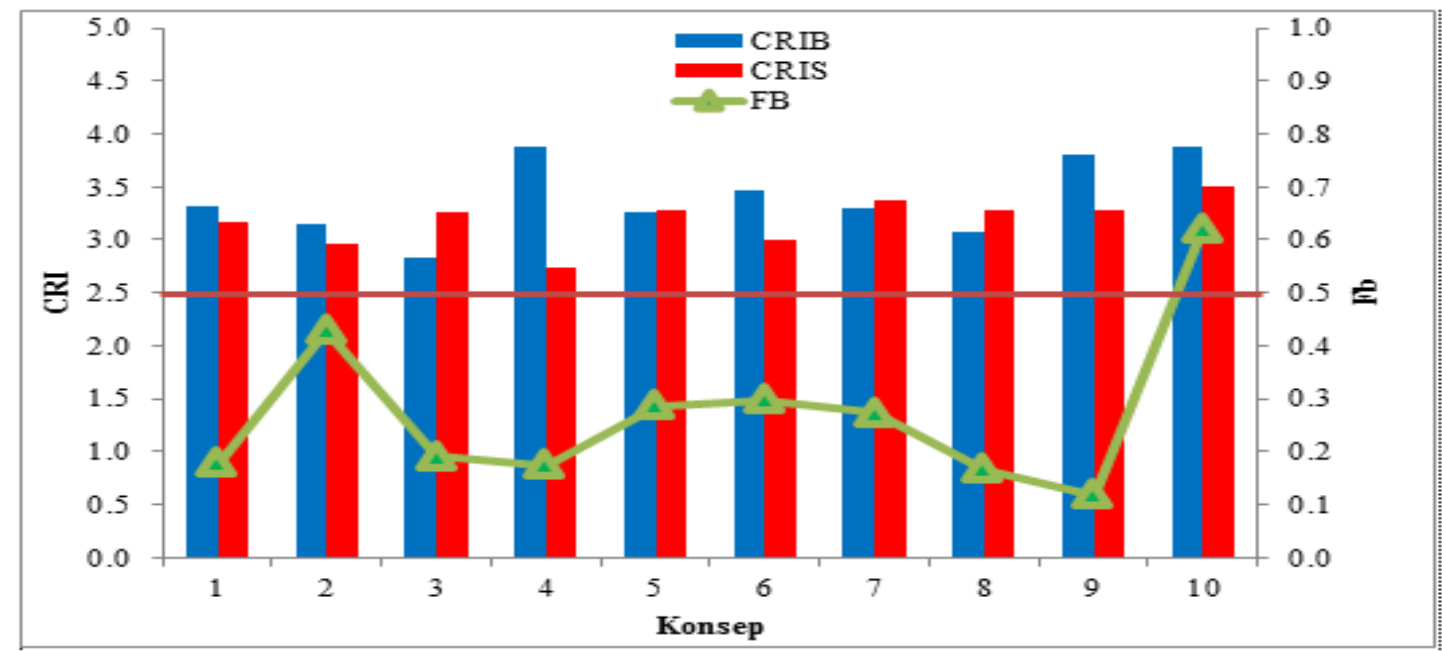

Gambar 3. Grafik Perbandingan CRIB, CRIS, dan fb Kelas A Program Studi Pendidikan Kimia FKIP yang TK, TTK, dan MK pada Pelaksanaan Pretest

Berdasarkan Gambar 3 diperoleh hasil analisis yaitu (1) miskonsepsi terjadi jika rata-rata nilai CRIS $(2,5<$ CRIS $\leq 0,5)$ dan $\mathrm{fb}<0,5$. Berdasarkan nilai CRIS dan fb pada setiap konsep yang diujikan terdapat mahasiswa yang mengalami miskonsepsi, (2) semua konsep memiliki nilai CRIS $>2,5$ dan sebagian besar $\mathrm{fb}<0,5$ dipahami oleh siswa secara miskonsepsi. Hal ini menujukkan bahwa respon secara miskonsepsi berdampak kuat kecuali konsep nomor 10 yang berdampak lemah karena nilai fb $>0,5$. Hasil ini memberikan informasi bahwa dalam proses pembelajaran dibutuhkan suatu model pembelajaran yang mampu meningkatkan pemahaman konsep mahasiswa secara mendalam dan menyeluruh. Hal ini sesuai dengan pernyataan Brasford dalam [11] bahwa pemahaman melibatkan proses-proses yang banyak menuntut pemikiran, seperti menjelaskan, menemukan bukti, menjustifikasi pemikiran, memberi contoh-contoh tambahan, generalisasi, dan menghubungkan bagian-bagian dengan keseluruhannya. Hasil penerapan model pembelajaran PS-TRILOGI diperoleh hasil seperti disajikan dalam Gambar 4.

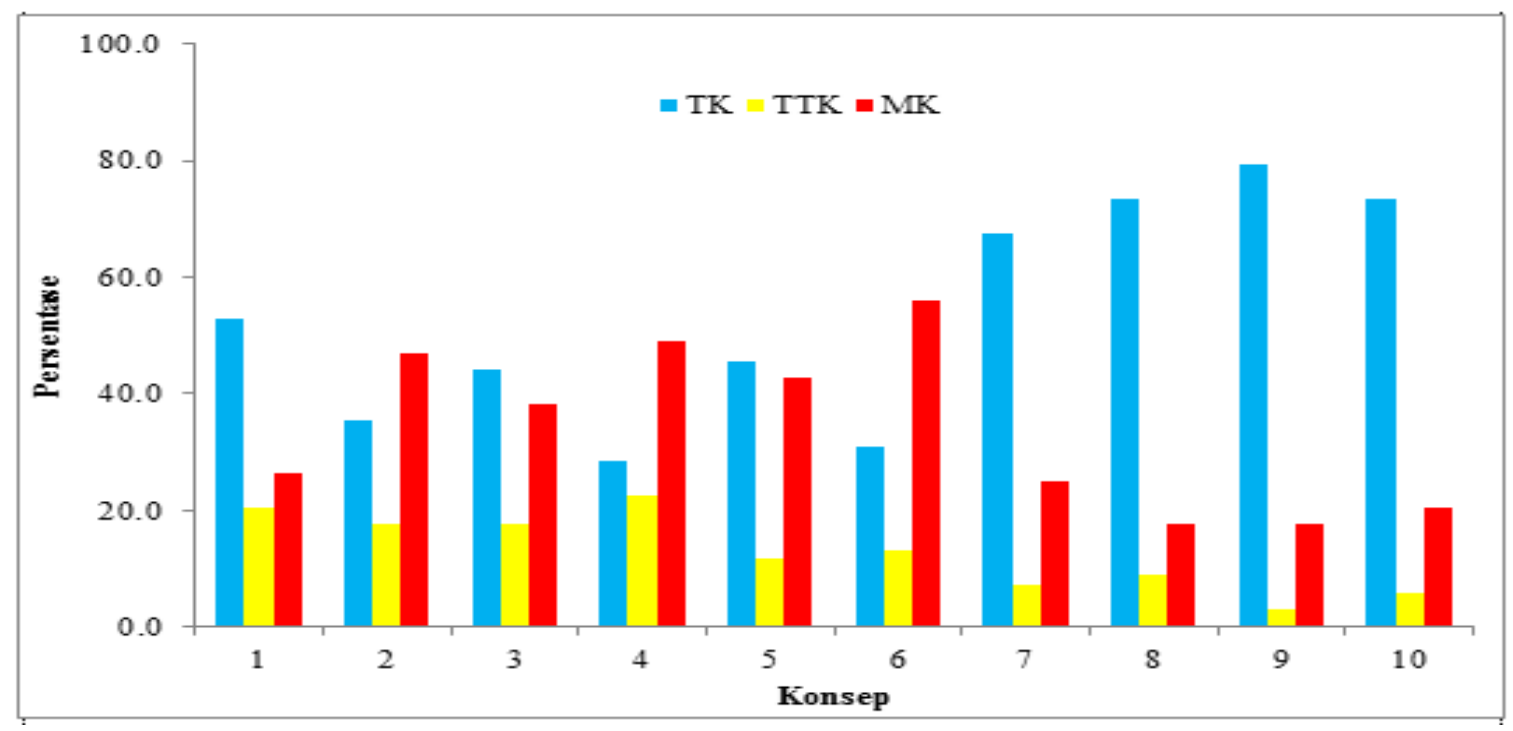

Gambar 4. Grafik Perbandingan Persentase Konsepsi Mahasiswa Kelas A Program Studi Pendidikan Kimia FKIP yang TK, TTK, dan MK pada Pelaksanaan Posttest 
Secara keseluruhan disajikan pada Gambar 5.

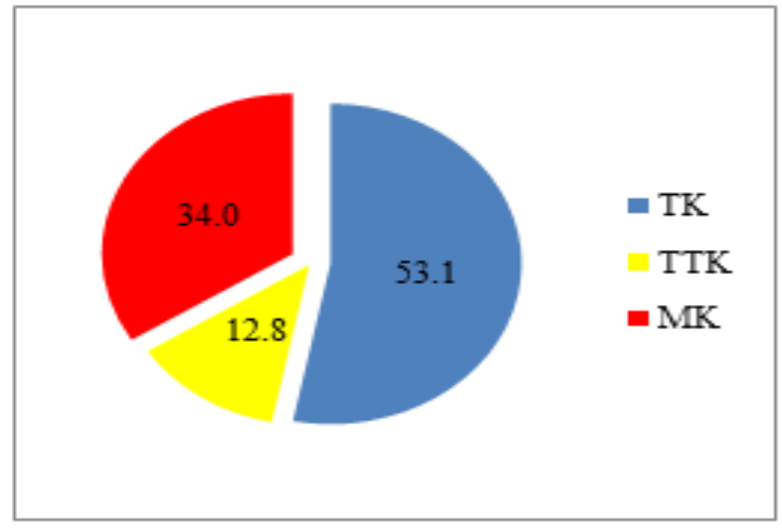

Gambar 5. Perbandingan Persentase Konsepsi Mahasiswa Kelas A Program Studi Pendidikan Kimia FKIP yang TK, TTK, dan MK pada Pelaksanaan Posttest

Berdasarkan Gambar 4 dan 5, tampak bahwa: (1) dari 10 konsep yang diujikan semua menyebabkan siswa mengalami miskonsepsi, (2) secara klasikal menunjukkan bahwa konsep yang direspon miskonsepsi secara kuat $(\mathrm{MK}>50 \%)$ terjadi pada konsep nomor 6, sedangkan konsep yang lain direspon miskonsepsi secara lemah (MK<50\%). Data CRIB, CRIS, dan fb yang dihitung dari hasil posttest disajikan dalam bentuk grafik seperti ditunjukkan pada Gambar 6 .

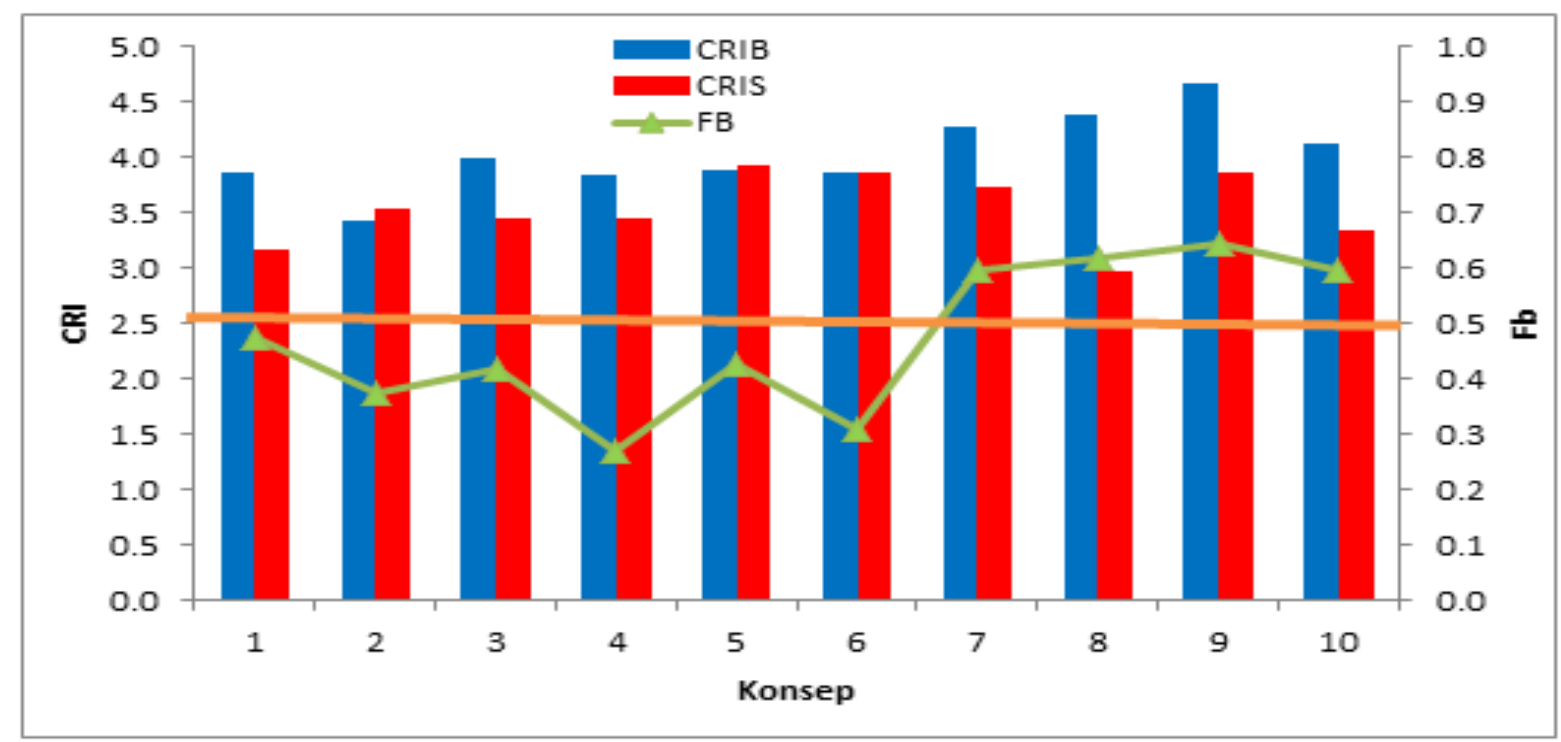

Gambar 6. Grafik Perbandingan CRIB, CRIS, dan fb Kelas A Program Studi Pendidikan Kimia FKIP yang TK, TTK, dan MK pada Pelaksanaan Posttest

Berdasarkan Gambar 6, menunjukkan bahwa respon secara miskonsepsi berdampak kuat masih terjadi pada konsep 4 dan 6. Artinya, penerapan model pembelajaran PS-TRILOGI di Kelas A Program Studi Pendidikan Kimia FKIP menyebabkan perubahan konsepsi mahasiswa secara klasikal menjadi TK sebesar 53,1\% (bertambah sebesar 28,7\%), TTK mengalami penurunan sebesar 16,6\% (dari 29,4\% menjadi 12,8\%), dan mahasiswa mengalami penurunan MK sebesar 12,2\% (dari 46,2\% menjadi 34,0\%. Secara ringkas persentase perubahan konsepsi mahasiswa pada pretest dan posttest disajikan dalam Tabel 4. 
Tabel 4. Perbandingan Persentase Konsepsi Mahasiswa Kelas A Program Studi Pendidikan Kimia FKIP yang TK, TTK, dan MK pada Pelaksanaan Pretest dan Posttest

\begin{tabular}{|c|c|c|c|c|c|c|c|c|c|c|}
\hline \multirow{2}{*}{$\begin{array}{l}\mathrm{N} \\
\mathrm{O}\end{array}$} & \multirow[b]{2}{*}{ Konsep } & \multicolumn{3}{|c|}{$\mathrm{MK}(\%)$} & \multicolumn{3}{|c|}{ TK $(\%)$} & \multicolumn{3}{|c|}{ TTK $(\%)$} \\
\hline & & $\begin{array}{l}\text { Pre } \\
\text { test }\end{array}$ & $\begin{array}{l}\text { Post } \\
\text { test }\end{array}$ & $\begin{array}{l}\mathrm{Re} \\
\text { duks } \\
\mathrm{i}\end{array}$ & $\begin{array}{l}\text { Pre } \\
\text { test }\end{array}$ & $\begin{array}{l}\text { Post } \\
\text { test }\end{array}$ & $\begin{array}{l}\text { Penin } \\
\text { g } \\
\text { katan }\end{array}$ & $\begin{array}{l}\text { Pre } \\
\text { test }\end{array}$ & $\begin{array}{l}\text { Post } \\
\text { test }\end{array}$ & $\begin{array}{l}\mathrm{Re} \\
\text { duksi }\end{array}$ \\
\hline 1 & $\begin{array}{l}\text { Komponen-komponen } \\
\text { larutan }\end{array}$ & 51,5 & 26,5 & 25,0 & 17,6 & 52,9 & 35,3 & 30,9 & 20,6 & 10,3 \\
\hline 2 & Tekanan uap larutan & 51,0 & 47,1 & 3,9 & 11,8 & 35,3 & 23,5 & 37,3 & 17,6 & 19,6 \\
\hline 3 & $\begin{array}{l}\text { Tekanan osmotik } \\
\text { larutan }\end{array}$ & 51,5 & 38,2 & 13,2 & 17,6 & 44,1 & 26,5 & 30,9 & 17,6 & 13,2 \\
\hline 4 & Molar & 42,2 & 49,0 & $-6,9$ & 18,6 & 28,4 & 9,8 & 39,2 & 22,5 & 16,7 \\
\hline 5 & Molal & 44,1 & 42,6 & 1,5 & 26,5 & 45,6 & 19,1 & 29,4 & 11,8 & 17,6 \\
\hline 6 & Fraksi mol & 36,8 & 55,9 & $\begin{array}{c}- \\
19,1\end{array}$ & 27,9 & 30,9 & 2,9 & 35,3 & 13,2 & 22,1 \\
\hline 7 & $\begin{array}{l}\text { Larutan } \\
\text { Buffer/penyangga }\end{array}$ & 47,1 & 25,0 & 22,1 & 27,9 & 67,6 & 39,7 & 25,0 & 7,4 & 17,6 \\
\hline 8 & $\begin{array}{l}\text { Kelarutan dan hasil } \\
\text { kali kelarutan }\end{array}$ & 58,8 & 17,6 & 41,2 & 10,3 & 73,5 & 63,2 & 30,9 & 8,8 & 22,1 \\
\hline 9 & Asam dan basa & 58,8 & 17,6 & 41,2 & 14,7 & 79,4 & 64,7 & 26,5 & 2,9 & 23,5 \\
\hline $\begin{array}{l}1 \\
0\end{array}$ & $\begin{array}{lll}\text { Titik beku } & \text { suatu } \\
\text { larutan } & & \\
\end{array}$ & 20,6 & 20,6 & 0,0 & 70,6 & 73,5 & 2,9 & 8,8 & 5,9 & 2,9 \\
\hline & -rata & 46,2 & 34,0 & 12,2 & 24,4 & 53,1 & 28,8 & 29,4 & 12,8 & 16,6 \\
\hline
\end{tabular}

Hasil yang diperoleh menunjukkan bahwa tidak semua mahasiswa terbebas dari miskonsepsi yang dimiliki. Hal ini adalah wajar karena pembelajaran dilakukan secara klasikal dengan durasi waktu yang sama untuk semua mahasiswa. Alasan ini didasarkan pada teori konstruktivisme bahwa peserta didik dalam mengkonstruksi pengetahuannya atau dalam membentuk skema, kategori, konsep, dan struktur pengetahuan mempunyai kecepatan yang berbeda-beda [13]. Terjadinya miskonsepsi pada konsep-konsep tertentu merupakan sebuah kewajaran karena tidak sedikit ahli di bidang pendidikan menyatakan bahwa mencegah terjadinya miskonsepsi pada siswa adalah hal yang sulit. Menurut [10] bahwa meskipun telah diperkenalkan dengan konsep yang benar masih terdapat peluang kembali kepada prakonsepsinya sendiri yang salah (miskonsepsi).

\section{Simpulan}

Penerapan model pembelajaran PS-TRILOGI berorientasi kearifan lokal mampu mereduksi Miskonsepsi (MK) mahasiwa pada materi Kimia Larutan sebesar 12,2\%; mampu meningkatkan Tahu Konsep (TK) mahasiswa sebesar 26,9\%; dan mampu mereduksi Tidak Tahu Konsep (TTK) mahasiswa sebesar $16,6 \%$. 


\section{Referensi}

[1] Afadil, (2016). Model Pembelajaran Problem Solving dengan Aspek Ontologi, Epistemologi, Aksaiologi (Model PS-TRILOGI) untuk Meningkatkan Kemampuan Berpikir Kritis dan Pemahaman Konsep Mahasiswa (Disertasi yang tidak dipublikasikan),Universitas Negeri Surabaya, Surabaya.

[2] Afadil, Wahid A., (2017). Analisis Perubahan Konseptual Mahasiswa Pada Materi Kinetika Kimia. Laporan Penelitian Lemlit Universitas Tadulako. Palu.

[3] Arends, R.I., (2008). Learning to Teach: Belajar untuk Mengajar. Yogyakarta: Pustaka Pelajar.

[4] Dahar, R.W. Teori-teori Belajar. Jakarta: Ditjen Dikti-P2LPTK, 2011.

[5] Dhindsa, Harkirat S. dan Treagust, David F. Conceptual Understanding of Bruneian Tertiary Students: Chemical Bonding and Struvture. Brune Int. J of Sci\&Math Edu. Vol. 1(1), 35-51, 2009.

[6] Effendy, 2014. Pembelajaran Kimia Secara Mendasar untuk Menjawab Tantangan dan Memenuhi Harapan Kurikulum 2013. Materi Seminar Nasional Kimia Universitas Negeri Gorontalo.

[7] Frankel, J.R., \& Wallen, N.E., (2009). How to Design and Evaluate Research in Education. $7^{\text {th }}$ Ed. McGraw-Hill Companies, Inc. New York.

[8] Hasan, S., Bagayoko, D., \& E. Kelley, Misconceptions and Certainty of Response Index. Journal of Physics Education, 34(5), 294-299, 1999.

[9] Horton, Christopher.2004. Student Preconceptions and Misconceptions in Chemistry (Student Alternative Conceptions in Chemistry. Modeling Instruction in High School Chemistry Action Research. Arizona State University.

[10] Ibrahim, M.. 2012. Konsep Miskonsepsi dan Cara Mengatasinya. Surabaya: Unesa University Press.

[11] Jacobsen D.A., Eggen P., Kauchak D., 2009. Methods for Teaching. Yogyakarta: Pustaka Pelajar.

[12] Janulis, P dan Ganti, Depari.Penelusuran Miskonsepsi Mahasiswa tentang Konsep dalam Rangkaian Listrik Menggunakan Certainty of Response Index dan Interview.http://file.upi.edu/Direktori/Makalah\%20Seminar/miskonsepsi\%20\%28Invotec\%2 9.pdf, diakses tanggal 10 Mei 2018.

[13] Suparno, Miskonsepsi dan Perubahan Konsep dalam Pendidikan Fisika. Jakarta: Grasindo, 2005 